\title{
Effectiveness of Imposition of Tax Sanctions on the Compliance of Individual Taxpayers in Reporting SPT in Jayapura City
}

\begin{abstract}
Herry M. Polontoh, Tri Yanuaria
Lecturer at Faculty of Law, Cenderawasih University

Abstract

This research is entitled as Effectiveness of Imposition of Tax Sanctions on the Compliance of Individual Taxpayers in Reporting SPT (Notification Letter) in Jayapura city. It aimed to see how effective the imposition of tax sanctions on the compliance of taxpayers in reporting SPT in Jayapura city due to the new policy stated that starting from 1 January 2008, taxpayers who have not reported their SPT or have reported their SPT containing incorrect or incomplete information and could disadvantage the country would not be punished with criminal sanctions. Instead, they will be punished with administration sanction if such failure was conducted for the first time. The mentioned administrative sanction is equal to $200 \%$ of the underpaid tax. This research used normative juridical and empirical juridical methods which collected data in the field and connected it with the relevant theories on the effectiveness of law enforcement. This research found that KPP Pratama Jayapura have not optimally enforced the administrative sanction in the form of fine towards individual taxpayers who have not reported their SPT (notification letter) due to the reason that in releasing SPT, Account Representatives (AR) still prioritize taxpayers who bring greater income to the state considering that the performance burden of AR is affected by the target work load. Based on the data of KPP Pratama Jayapura, it could be concluded that the level of compliance of the taxpayers in reporting their annual SPT from 2015 to 2017 did not increased as there is legal uncertainty in the imposition of sanctions towards taxpayers which makes disobedience from taxpayers. The factors that inhibit the implementation of sanctions are (1) the absence of awareness and low knowledge of taxpayers regarding their tax obligations; (2) the range of control between the residence of the taxpayer with the tax service office which results in the need for a large budget in the case of notification / collection of tax administration fines; and (3) taxpayer identity is invalid which make it difficult for officers to send the SPT to taxpayers. Researchers suggested that a model for applying tax sanctions is required in order to conform to the principles of tax law.
\end{abstract}

Keywords: Imposition, Tax Sanctions, Annual SPT, Jayapura

DOI: $10.7176 / J L P G / 83-17$

Publication date: March $31^{\text {st }} 2019$

\section{Introduction}

Tax is a form of contribution to the country which could be forced to the taxpayers to be paid in accordance with the regulation without direct feedback, could be directly pointed, and and aims to fund general expenses which are related to the government task ${ }^{1}$.

Reporting annual income tax (PPh) SPT could be exercised in two ways. The first one is by directly come to the KPP Pratama Jayapura, through Account Representatives (AR) which are tasked to perform supervision on the compliance of the taxpayers, provide guidance and instruction as well as consultation on techinaclity of the tax to the tax payers, arrangement of tax payers' profiles, tax payers working analysis, tax payers' data reconciliation in terms of intensification and conduct evaluation of appeals based on applicable provisions. Each taxpayer will be assisted in fulfilling their SPT. The second way is through online application. Thus, it does not require much time to report the SPT. It is easier for the taxpayers as they could report their SPT anywhere. It could not be denied how difficult collecting the tax is for the government as many taxpayers have not complied in either paying or reporting their SPT. On the other hand, tax is one form of income for the country which will be used for development with aims for welfare and prosperity of the people.

Between January and March, people and workers who have salary is under obligation to report their annual income tax (PPh) SPT. However, some of them are still lazy to report their tax SPT with numbers of reasons. For the workers, many of them are questioning the obligation to report the SPT as they assume that their taxes have been paid by their offices. In fact, the applicable law stated that income tax SPT must be reported. Consequently, those who have not reported or failed to report it during the given time will be punished by the regulated sanction.

Obligation to Report SPT has been ruled under Law No.28 of 2007 concerning the third ammandement of Law No.6 of 1983 concerning General Provisions and Tax Procedures. This law is known as KUTAP Law. The

\footnotetext{
${ }^{1}$ Bohari, 2004, Introduction of Tax Law (Pengantar Hukum Pajak), PT Raja Grafindo Persada, Jakarta, p. 23
} 
definition of Notification Letter or SPT is explained in article 1 paragraph 10 of the KUTAP Law which stated that SPT is a notification letter by the taxpayers which is used to report the calculation and the payment of payable taxes in accordance with the provisions within Tax Laws. Furthermore, it has functions as the tools for the taxpayers to report and be responsible for the calculation of their taxes which have to be paid and to report their tax payments that have been carried out by themselves or through deductions or collection of other parties in one tax year or part of the tax year, income that is classified as an object of tax and / or not an object of tax, as well as assets and liabilities of payment from the deduction or tax collection of another person or entity in 1 tax period in accordance with the provisions of the tax law.

SPT that have not been reported or reported not in accordance with the specified time limit will be subject to administrative sanctions in the form of fines:

1. Individual Annual Income Tax (PPh) SPT Rp 100.000,00.

2. Institution Annual Income Tax (PPh) SPT Rp 1.000.000,00.

3. VAT SPT Rp 500.000,00.

4. Other SPT Rp 100.000,00.

Starting from 1 January 2008, taxpayers who have not reported or reported their SPT with incorrect or incomplete and disadvantage the country would not be punished with criminal sanctions. Instead, it would be punished with administrative sanctions if such failure is conducted for the first time. Such administrative sanction is equal with an increase of $200 \%$ of the tax that is underpaid. Nevertheless, in reality, there are still a lot of taxpayers who have not reported their SPT either individual or institutions in KPP Pratama Jayapura. This is what the researchers wanted to discover on how effective the imposition of the individual taxpayers who do not reported their SPT and what obstacles affecting it.

The previously explained background becomes the bases for the writers to exercise this research regarding the Effectiveness of Imposition of Tax Sanctions on the Compliance of Individual Taxpayers in Reporting SPT (Notification Letter) in Jayapura. Moreover, the research questions of this paper are the following: How effective the imposition of the tax sanctions on the compliance of the taxpayers in reporting their SPT in Jayapura? And What factors affecting the effectiveness of the imposition of tax sanctions on the compliance of taxpayers in reporting their SPT in Jayapura?

\section{Methodology}

The research methodologies that were used in this research are the normative juridical and empirical juridical methods that focused on literature research and data from empirical research which consists of interview with 4 staffs (AR and Department of Data Processing) of KPP Pratama Jayapura and 10 individual taxpayers in University of Cendrawasih as well as 10 people in State-Owned-Enterprises.

Data analysis method that was used by the writer is descriptive analysis which means that data that has been collected and classified is then analysed and systematically described in accordance with the reality of the facts, the characteristics and relations between the investigated events so that they can be justified. The analysis limits the discussion, which means there is no confusion, so that the discussion is on target.

\section{Results and Discussion}

\subsection{Effectiveness of the Imposition of Tax Sanctions on the Compliance of the Tax Payers in Reporting SPT in Jayayapura City}

The definition of SPT is explained within Article 1 paragraph 10 of the KUTAP Law which stated that "SPT or notification letter is a a letter by the taxpayers that is used to report the tax calculation and payment in accordance with the tax regulated provisions". It clarifies how much is tax obligation of the taxpayers that shall be paid and reported to the country. Before discussing what kind of sanctions are available if the taxpayers do not report their Income Tax SPT, it is better to understand what types of obligation lyed for the taxpayers related to the SPT, namely:

a. Reporting the monthly tax SPT.

b. Reporting the annual tax SPT (Consists of PPh Institution, Individual $\mathrm{PPh}$ and $\mathrm{PPh}$ in accordance with article 21). 
c. Payment of tax debt listed in the tax assessment letter and other decision letters.

In accordance with article 3 of Law No. 28 of 2007, SPT has functions as follow:

a. $\mathrm{PPh}$ Taxpayers

It has functions as the tools for the taxpayers to report and be responsible for the calculation of their taxes which have to be paid and report the collection of another party in one tax year or part of the tax year.

- Income that is classified as an object of tax and or not an object of tax.

- Assets and liabilities.

- $\quad$ Payment from the deduction or tax collection of another person or entity in 1 tax period in accordance with the provisions of the tax law.

b. Taxable Employer (PKP)

As the tools for the taxpayers to report and be responsible for the calculation of actual payable valueadded tax (VAT) and Sales tax on luxury goods (PPnBM) and to report things related to:

- Credits of income tax on outcome tax.

- Payments of taxes that have been carried out by the PKP itself and / or through other parties in a tax period, which is determined by the provisions of the applicable tax laws and regulations

c. Tax Cutter/ Collector

As a means to report and to be held accountable for taxes that are deducted or collected and deposited.

In order to achieve god administration, both taxpayers and tax officials need to comply with their obligations. It is related to the realization of tax elements that can be forced as the definition of tax. Thus, it is concluded in tax sanctions, including those related to sanctions for taxpayers who do not report their annual tax SPT. Sanctions in taxation consist of administrative sanctions which include sanctions in the form of fines, sanctions in the form of interest, sanctions in the form of increases, as well as tax criminal sanctions which include violations of sanctions and criminal sanctions of a criminal nature. ${ }^{1}$ Administrative sanctions in the form of fines for delays in carrying out SPT report that are not reported or reported not in accordance with the specified deadline, then are subject to administrative sanctions in the form of fines:

1. Individual Annual Income Tax (PPh) SPT Rp 100.000,00.

2. Institution Annual Income Tax (PPh) SPT Rp 1.000.000,00.

3. VAT SPT Rp 500.000,00.

4. Other SPT Rp $100.000,00$.

Starting from 1 January 2008, taxpayers who have not reported or reported their SPT with incorrect or incomplete and disadvantage the country would not be punished with criminal sanctions. Instead, it would be punished with administrative sanctions if such failure is conducted for the first time. Such administrative sanction is equal with an increase of $200 \%$ of the tax that is underpaid. Based on the field research that had been conducted, the results of the level of the compliance in reporting SPT in KPP Pratama Jayapura from 2015 to 2017 could be seen in the following table:

\footnotetext{
${ }^{1}$ Adrian Sutedi, 2011, Tax Law (Hukum Pajak), Sinar Grafika, Jakarta, p. 221
} 


\section{KPP Pratama Jayapura Data}

Table 1

Registed Taxpayers

\begin{tabular}{|c|c|c|c|}
\hline \multirow{2}{*}{ Registed Taxpayers } & 2015 & 2016 & 2017 \\
\cline { 2 - 4 } & 127.307 & 149,017 & 170,875 \\
\hline Institutions & 14,411 & 18,835 & 20,762 \\
\hline Labour Organisation & 112,895 & 130,182 & 150,113 \\
\hline
\end{tabular}

Table 2

Realization Table that reports Annual SPT

\begin{tabular}{|c|c|c|c|c|}
\hline \multicolumn{2}{|c|}{} & 2015 & 2016 & 2017 \\
\hline No & $\begin{array}{c}\text { Taxpayers who report their annual } \\
\text { SPT }\end{array}$ & 23.843 & 35,250 & 39,829 \\
\hline 1 & Institutions & 3,191 & 3.450 & 3731 \\
\hline 2 & Labour Organisation & 20.652 & 31.800 & 36,098 \\
\hline & Level of Compliance & 0,18 & 0,23 & 0,23 \\
\hline
\end{tabular}

From the above table, it can be seen that in 2015 with 127,307 taxpayers, there are 23,843 taxpayers who reported their SPT; in 2016 which consists of 149,017 taxpayers, there are 35,250 taxpayers who reported their SPT and finally in 2017 from 170,875 taxpayers, there are 39,829 taxpayers who reported their SPT. Therefore, it can be concluded that the level of compliance of the taxpayers from 2015 to 2017 have not increased.

Based on the results of the interview, it was found that the impositions of administrative sanctions on institution or individual taxpayers who did not report their annual SPT were not optimal. It is due to the reason that AR in issuing STPs (Tax Collection Letters) still saw and considered the potential of state revenue and pursuit of work targets. Thus, the imposition of the sanctions for the taxpayers who did not report their SPT is still seen from the priority scale. ${ }^{1}$ Specifically for individual taxpayers, the sanctions given are quite low with a fine of Rp.100,000 thousand. This is also related to the principle of taxation which states that in carrying out tax collection with administrative sanctions, the costs for collecting administrative sanctions may not be greater than administrative sanctions in the form of fines for non-compliance of reporting SPT.

The law enforcement could be normally exercised in society because each individual obeys the rules with awareness, that is whatever ruled by the law is mandatory or as something that is better if it is applied. Law enforcement could also be conducted because of violations of the law, namely by upholding the law with the help of state equipment in case the taxpayer is a tax officer or tax employee. The Law enforcement is an attempt to realize ideas about justice, legal certainty and social benefits into reality. The process of manifesting ideas is the essence of law enforcement. ${ }^{2}$ Law enforcement in imposing sanctions on taxpayers is the application of power tools as a reaction to violations so that the creation of legal oversight and increasing deterrent effects for the community to realize a sense of justice, legal certainty and benefit from the application of sanctions in order to create legal order and increase the deterrent effect for the community to realize a sense of justice, legal certainty and benefit from the application of sanctions.

\footnotetext{
${ }^{1}$ Results of interview with AR represented by Mega, on 13 September 2018

${ }^{2}$ Satjipto Rahardjo in Riduan Syahrani, Executive Summary of Legal Science (Rangkuman Intisari Ilmu Hukum), p. 192..
} 
Of course it will affect the taxpayers compliance in reporting their annual SPT. Because until now the imposition of administrative sanctions for taxpayers who do not report their SPT has not been effectively imposed. Out of 10 individual taxpayers who do not report their SPT, none of the them is subject to administrative sanctions in the form of fines.

The right to collect taxes, including interest, penalties, increases and collection fees, expires after 10 years from the time the tax becomes due or the tax period, part of the tax year, or the concerned tax year. When expired, tax collection needs to be established to provide legal certainty when the tax debt cannot be collected again. Surely, it will affect the time period of the billing of the imposition of the administrative fine. There will be a long period of time that allows the imposition of administrative sanctions in the form of fines for individual taxpayers to be optimized.

\subsection{Factors that affect the Effectiviness of Imposition of Tax Sanctions on the Compliance of the Tax Payers in Reporting SPT in Jayapura City}

Every taxpayer fills the SPT in accordance with regulations 534/KMK.04/2000 or KEP - 185/PJ/2003, either in the form of paper application or electronic application with correct, complete, Clear, in Bahasa Indonesia with alphabet, Arabic numerical, rupiah currency, and signed. It is then submitted to the Tax General Office where the taxpayer is register or confirmed by the Tax General Director.

The definitions of correct, complete and promt in fulfilling the SPT are:

1. Correct in calculation, including in the application of the tax regulatory provisions, in writings, and in accordance with the factual circumstances.

2. Complete all the elements related to tax object and other elements that shall be reported in SPT.

3. Clarity in reporting all the sources of the tax objects and other elements that shall be reported in SPT.

In case the SPT was fulfilled and signed by person other than the taxpayers, special procuration must be attached. For the institution tax payers, SPT must be signed by its directors or boards.

Exceptions of the imposition of fine sanctions arenregulated under article 7 (2) of the UU KUP. Those exceptions are:

1. Non-Effective Tax Payers

2. Individual Tax Payers who have passed away but their heirs have not submitted written notification to the KPP.

3. Institution Tax Payers who no longer conduct business activity yet has not been disbanded.

4. Taxpayers whose address have not been able to be identified.

In accordance with the previous provisions, the imposition of tax sanctions especially tax authorities that will impose sanctions on taxpayers who do not report their annual SPT must pay attention to such matter. Nevertheless, in carrying out their duties, AR (Account Representative) have tasks to perform supervision of taxpayer compliance, taxation guidance / technical advice and consultation to taxpayers, profile of taxpayers, analysis of taxpayer performance, reconciliation of taxpayer data in the context of intensification and evaluation of appeals based on applicable provisions. This matter will also affect the performance of each AR in carrying out their obligations as they are required to fulfill the work target which is also part of their workload. Consequently, in issuing a Tax Collection Letter (STP), AR prioritizes taxpayers who can contribute a greater income to the country. ${ }^{1}$

In determining the granting of STP, AR also uses the principle in tax collection, namely the operational or collecting fee may not be greater than the tax to be received by the State. This is issue is related to the scope of work from AR, where KPP Pratama works based on region or area and as we have known, the area of Jayapura is very wide. In addition, KPP Pratama Jayapura still lacks of tax officials.

The constraints faced by the KPP Pratama Jayapura in implementing administrative sanctions for taxpayers who do not report their SPT are as follows:

a. The absence of awareness and low knowledge of taxpayers regarding their tax obligations

b. Range of control between the residence of the taxpayer with the tax service office which results in the need for a larger budget in the case of notification / collection of tax administration fines

\footnotetext{
${ }^{1}$ Results of interview with AR represented by Mega, on 13 September 2018.
} 
c. Taxpayer identity is invalid which make it difficult for officers to send the SPT to taxpayers.

d. Taxpayers whose addresses are not complete or not correct.

e. Individual taxpayers have passed away.

f. Individual taxpayers who no longer conduct business or work as freelancer.

g. Individual taxpayers with status as foreign nationals who no longer live in Indonesia.

h. Permanent Establishments who no longer conduct activities in Indonesia.

i. Institution taxpayers who no longer carry out business activities but have not disbanded in accordance with applicable regulations.

j. Treasurer who does not make payments anymore.

k. Taxpayers affected by the disaster.

1. Lack of power

With counseling provided by the government, it is hoped that the community will truly understand the tax and its function for the welfare of the nation, feeling interested so that public awareness in paying taxes can be increased. Taxpayers do not directly feel the benefits of paying taxes, but actually the tax-derived tax funds are used by the government to build infrastructure and services for the public.

\section{Conclusions}

It can be coluded that:

1. The imposition of administrative sanctions in the form of fines by KPP Pratama Jayapura for individual taxpayers who do not report SPT (Notification) has not been carried out optimally because in issuing STP (Tax Collection Letter) AR still prioritizes taxpayers that bring greater income to the country. This is also due to AR performance burden that is affected by the target workload burden. Based on data from KPP Pratam Jayapura, it can be said that the level of compliance of the taxpayers in reporting their annual SPT from 2015-2017 had not increased due to legal uncertainty in imposing sanctions to taxpayers who do not obey their obligations.

2. The factors that affect the imposition of tax administration sanctions are the absence of awareness and low knowledge of taxpayers regarding their tax obligations; Range of control between the residence of the taxpayer with the tax service office which results in the need for a larger budget in the case of notification / collection of tax administration fines; Taxpayer identity is invalid which make it difficult for officers to send the SPT to taxpayers; Taxpayers whose addresses are not complete or not correct; Individual taxpayers have passed away; Individual taxpayers who no longer conduct business or work as freelancer; Individual taxpayers with status as foreign nationals who no longer live in Indonesia; Permanent Establishments who no longer conduct activities in Indonesia; Institution taxpayers who no longer carry out business activities but have not disbanded in accordance with applicable regulations; Treasurer who does not make payments anymore; and Taxpayers affected by the disaster.

\section{Bibliography}

Adrian Sutedi, Tax law (Hukum Pajak), Sinar Grafika, Jakarta, 2011

Arinta Kastadi. System and Regulation of Indonesian Taxes (Sistem dan Peraturan Perpajakan Indonesia), Alumni, Bandung, 1984.

B. Usnian dan K. Subroto, Indonesian Taxes (Pajak-Pajak Indonesia). Yayasan Bina Pajak, Jakarta, 1980.

Bomer Pasaribu, Hukum Pajak dan Pelayanan Masyarakat, Berita Pajak No. 1114, Jakarta, 1989.

B. Ilyas Wirawan dan Burton Richard, Hukum Pajak, Salemba Empat, Jakarta, 2007.

Bohari, Introduction of Tax law (Pengantar Hukum Pajak), PT Raja Grafindo Persada, Jakarta 2004.

Eddy Pelupessy and Tri Yanuaria, Tax Law (Hukum Pajak), Logos, Bandung, 2017. 